\title{
Glucose transport in human red blood cells
}

\author{
Omar S. Hajjawi
}

Department of Biology, Arab American University, P.O. Box 240, Jenin, Israeli Occupied Territories of Palestine

Email address:

ohajjawi@aauj.edu

\section{To cite this article:}

Omar S. Hajjawi. Glucose Transport in Human Red Blood Cells. American Journal of Biomedical and Life Sciences. Vol. 1, No. 3, 2013, pp. 44-52. doi: 10.11648/j.ajbls.20130103.12

\begin{abstract}
The penetration of D- $\left[{ }^{14} \mathrm{C}\right]$ glucose into human red blood cells (RBCs) features kinetic parameters which are readily distinguishable from passive permeation. It would be expected to require activation energy above $80 \mathrm{~kJ} / \mathrm{mol}$ for permeation of glucose with five hydroxyls capable of forming hydrogen bonds, but the measured activation energy is approximately $16 \mathrm{~kJ} / \mathrm{mol}$. As a consequence, glucose permeates RBC membrane about five orders of magnitude faster than would be expected for passive permeation. Glucose transporter protein 1, or GLUT1 and SGLT1, present in all human tissues, but especially in RBCs. It is also anchored in the protective sheet of flat cells that line up the blood vessels of the brain. GLUT1 has a strong affinity for glucose and it ensures that both RBCs and the brain receive appropriate levels of glucose that they need to be able to function. The brain consumes $\sim 120 \mathrm{~g}$ of glucose per day; the blood glucose level in a typical person $80 \mathrm{mg} / 100 \mathrm{ml}$. The binding site of glucose faces intracellular and extracellular of the membrane alternately when it is loaded by a glucose. The transport is accomplished by conformational changes within GLUT1, and not by rotation of the whole single long polypeptide chain $(55 \mathrm{kD}, \sim 500$ residues) with the presence of 12 trans membrane $\alpha$ helices segments. The super family of related GLUT sugar transporters comprises 14 identified isoforms in the human genome, all adopting a 12-membrane-spanning domain structure that delineate 6 extracellular loops .The erythrocyte glucose transporter GLUT1 has an $\sim 10$-fold-lower affinity for D-glucose, $K_{\mathrm{m}} \approx 10-15 \mathrm{mM}$, at the inside face for net export than on the outside $\left(K_{\mathrm{m}}=1-2 \mathrm{mM}\right)$ for net import of glucose (zero-trans net flux) at $24^{\circ} \mathrm{C}$, pertaining a liganded consequential asymmetric transporter.
\end{abstract}

Keywords: D- $\left[{ }^{14} \mathrm{C}\right]$ Glucose Transporter (GLUT1), Secondary Active Glucose Transporter (SGLT), Membrane Transport, Glucose Transporter Gene (GLUT1 cDNA), Erythrocytes, Glycogenolysis, Diabetes Mellitus, D-Glucose, Facilitated Transport, Cytochalasin B (CB), $\mathrm{Na}^{+} / \mathrm{K}^{+}$-ATPase Pump, Carbamazepine, Simvastatin.

\section{Introduction}

The mature RBC (erythrocyte) of the normal allele $\mathrm{Hb}^{\mathrm{A}}$ is flexible and oval biconcave disc $8 \times 8 \times 1$ to $2 \mu \mathrm{m}$ with a volume of $80 \mu \mathrm{m}^{3}[1,2]$. A $0.9 \% \mathrm{NaCl}$ solution is isotonic with plasma [3]. RBC lacks a cell nucleus and most organelles. New erythrocytes are produced $\sim 2.4$ million per second, and an erythrocyte circulates for about 100-120 days in the body before its components are recycled by macrophages [4]. Since RBC has no mitochondria and enzymes of citric acid cycle and oxidative phosphorylation, adenine triphosphate synthesis takes place through glycolysis.

Passive and mediated permeations are more generally distinguishable on the basis of differences in the kinetics and specificities of the two processes [5]. When the change in the intracellular concentration is measured as a function of time in a facilitated transport system in a single experiment, the results appear very much like a simple diffusion process (Fig.1), since the final intracellular concentration equals the extracellular concentration, $[\mathrm{C}]_{\mathrm{i}}=$ $[\mathrm{C}]_{\mathrm{o}}$. It is only when the concentration of extracellular is varied and competing chemical molecules are added to the system that specificity, saturation and competition are demonstrated. A system that moves substrate by facilitated diffusion carriers across the membrane of RBCs is invariably of limited capacity and it should eventually become saturated [6]. As the substrate gradient is increased, the rate of substrate permeation would be expected to approach and maintain a maximum provided that the substrate concentration can be raised to an appropriate level. This unidirectional flux of substrate across the RBC membrane is described approximately by adopting a Michaelis-Menten [7] type expression:

$$
J_{1 \rightarrow 2}=J_{\max }[\mathrm{C}]_{1} / K_{m}+[\mathrm{C}]_{1}
$$


where $J_{1 \rightarrow 2}$ is flux from compartment 1 to compartment 2,

(A) Facilitated transport

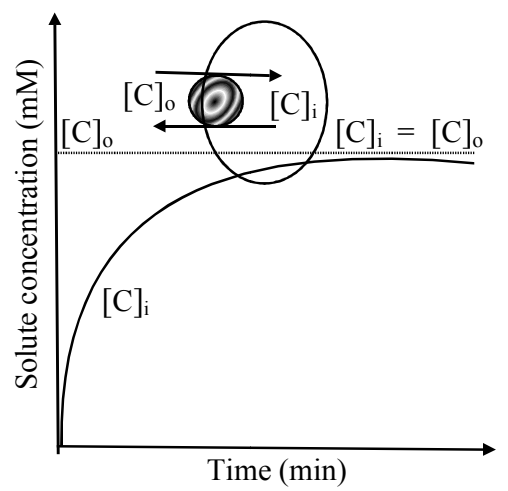

$J_{\max }$ is maximum rate of flux,

(B) Active transport

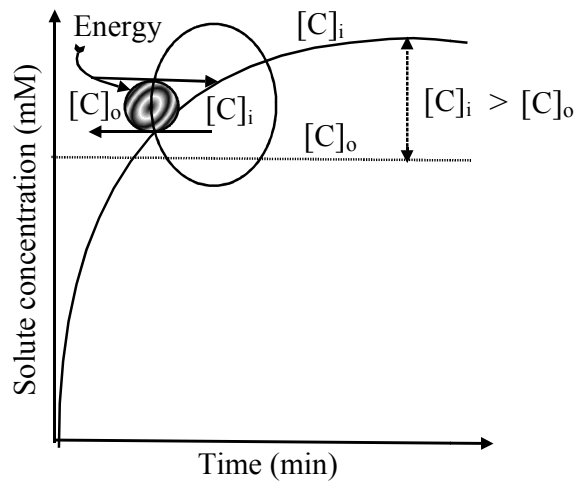

Fig 1. Time course of changes in human RBC intracellular concentration $[C]_{i}$ during (A) facilitated transport, resulting from the permeation of extracellular solute molecules; (B) active transport, resulting in an intracellular concentration of solute higher than the exctracellular concentration [C] i.e. the value at saturation of the mediated system and $[C]_{1}$ is the concentration of glucose in compartment 1 . The net flux in these terms would be:

$$
J_{1 \rightarrow 2}=J_{\max }\left\{\left([\mathrm{C}]_{1} / K_{m}+[\mathrm{C}]_{1}\right)-\left([\mathrm{C}]_{2} / K_{m}+[\mathrm{C}]_{2}\right)\right\}
$$

The electrochemical gradient in many mediated permeation systems is maintained by removing the substrate from the second compartment, and the rate of mediated permeation is then closely approximated by:

$$
J_{1 \rightarrow 2}=J_{\max }[\mathrm{C}]_{1} / K_{m}+[\mathrm{C}]_{1}
$$

This formal similarity to enzyme kinetics means that certain types of mathematical calculations can be used to determine $J_{\max }$ and $K_{m}$, and also to characteristics such as specificity, competitive inhibition, $\mathrm{pH}$ dependence, temperature dependence, specific inhibition of the mediated permeability [8].

Glucose is transported across RBC membranes by a uniport; that is, transporters carry only a single type of substrate across the membrane [9,p.395]. Glucose concentration in the blood is carefully regulated $(80 \mathrm{mg} / 100 \mathrm{ml}, 4.4-8 \mathrm{mM})$, so that it is normally higher than intracellular concentrations. As soon as glucose enters the cell, it is converted into other chemicals (Fig.2) needed for energy production or biosynthesis and to maintain intracellular concentration much lower than $5 \mathrm{mM}$ normal level in the blood.

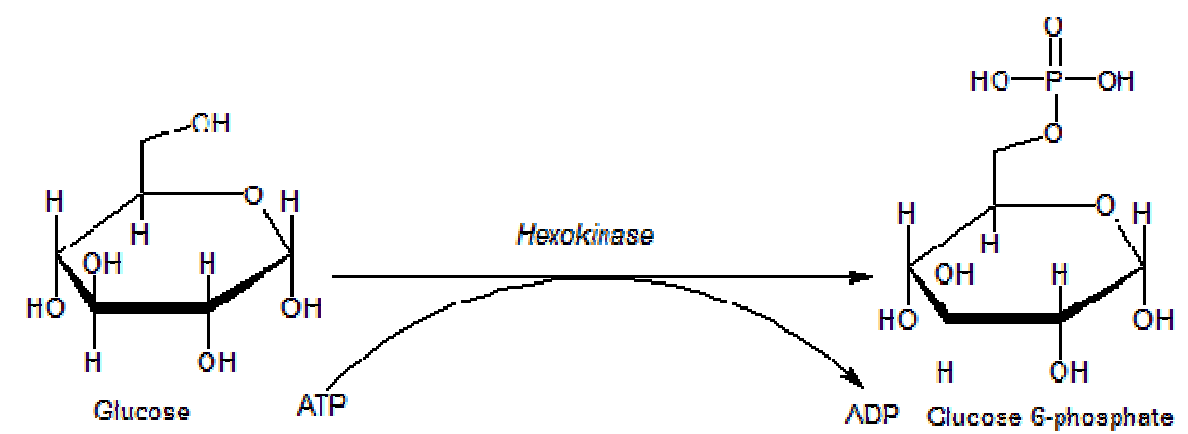

Fig 2. The formation of a phosphate ester of glucose. Adenosine triphosphate is the phosphate group donor. The enzyme [2.7.1.1 or 2.7.1.2.] specifies the interaction with $-\mathrm{CH}_{2} \mathrm{OH}$ on carbon 6 of $\alpha--D$ - Glucose ( $\alpha-D$ - Glucopyranose). Adapted from: Stryer, L. (1995) Biochemistry, $4^{\text {th }}$ edn., p.571. New York, NY: H.W. Freeman and Company.

In hereditary spherocytosis (congenital hemolytic icterus), the cells are spherocytic in normal plasma and hemolyze more readily than normal cells in hypotonic $\mathrm{NaCl}$ solutions. RBCs can also be lysed by drugs and infections. The susceptibility of RBCs to hemolysis by these agents is increased by deficiency of the enzyme glucose-6-phosphate dehydrogenase $[10,11]$, which catalyzes the initial step in the oxidation of glucose via hexose monophosphate shunt aerobic minor pathway [9]. This pathway generates nicotinamide adenine dinecleotide phosphate (NADPH) that is required to sustain normal fragility of the cell [12, 13]. Congenital deficiency of this enzyme is the commonest known genetically determined human enzyme abnormality [14].

However, glucose-6-phosphate dehydrogenase [1.1.1.49], triose phosphate isomerase [5.3.1.1.], pyruvate kinase [2.7.1.40] and glutathione reductase [E.C.1.6.4.2] are essential human RBC enzymes in the pentose phosphate pathway in preventing haemoglobin oxidation [15]. The deficiency of these enzymes cause the failure of this mechanism that would in turn result in oxidating, denaturing and precipitating haemoglobin as Heinz bodies $[16,17]$. 


\section{RBC Membrane Defect}

The cell membrane of the erythrocyte is a trilaminar bipolar phospholipid structure in which are anchored many types of integral structural proteins ; it is flexible and it is often referred to as "fluid mosaic structure" [18].

Rhesus ( $\mathrm{Rh}$ ) blood group antigens are transmembrane proteins with loops exposed at the surface of RBCs $[19,20]$. Very rare patients with the lack of Rh antigens have severe membrane abnormalities that result in deformed RBCs known as stomatocytes with an elongated (mouth-like) area of central pallor that shortens survival times [21]. The ABO glycoprotein blood group antigens are located on the outer surface of the membrane and they are not integral structural proteins of the membrane [22].

Spherocytosis congenital autosomal dominant disease, i.e. a familial hemolytic disorder condition that causes an abnormality in the RBC membrane [23,24]. Elliptocytosis (ovalocytosis) is a rare autosomal dominant disorder that resembles spherocytosis except that the RBCs are varying in shape from elongated to oval and the disease is less severe, associated with mild splenomegaly [25]. They can be seen in hereditary disorders or in acquired disorders, such as iron deficiency anemia, infectious anemia, thalassemia, and in newborn babies [26]. Paroxysmal nocturnal haemoglobinuria is an acquired disorder characterized by a defect in the glycosylphosphatidylinositol anchor that leads to the premature death and impaired production of RBCs [27, 28].

\section{Materials and Methods}

D- $\left[{ }^{12} \mathrm{C}\right]$ Glucose and $\left[\mathrm{U}-{ }^{3} \mathrm{H}\right]$ inulin were purchased from Radiochemical Centre, Amersham, Buck, UK;Silicon oil was purchased from Hopkin and Williams, Romford, Essex, UK. All other materials were supplied by Sigma (London) Chemical Co., Poole, Doreset, UK, or by BDH Ltd., Poole, Dorset, UK, and were of AnalaR grade whenever possible. All solutions were prepared with glass-distilled water.

\section{Erythrocyte Preparation}

Freshly outdated blood containing citric acid, sodium citrate, dextrose and adenosine was collected from Essex Country Hospital, Colchester, UK. Unfortunately, the gender, age and lifestyle of blood donors were anonymous for making comparative analysis. Human erythrocytes were separated by sedimentation at $2500 \mathrm{~g}$ (at rav $13 \mathrm{~cm}$ ) and $4^{\circ} \mathrm{C}$ for 5 min using MSE Mistral 4L. The plasma and buffy coat were removed by aspiration. The erythrocytes were then washed three times by re-suspension and sedimentation in ice-cold $\mathrm{NaCl}(152 \mathrm{mM})$. Finally, erythrocytes were suspended in Krebs-Ringer bicarbonate [29] at $\mathrm{pH} 7.4,1: 1(\mathrm{v} / \mathrm{v})$ for isotope flux studies, and kept on ice.

Erythrocytes were always used for experiments immediately after preparation. The volume of erythrocyte intracellular water (68.8\%) was determined with the use of [3H]inulin as described by Winter and Christensen [30] for rabbit erythrocytes. The standard dry weight of erythrocyte suspension (typically $\sim 30 \%$ ) was used to calculate the intracellular fluid for each experiment.

\section{D- $\left[{ }^{12} \mathrm{C}\right]$ Glucose Flux Studies}

$\mathrm{D}-\left[{ }^{12} \mathrm{C}\right]$ Glucose influx was measured using a slight modification of the procedure reported by Eavenson and Christensen [31] for pigeon erythrocytes. An iso osmotic glucose/sucrose solution ( $1 \mathrm{ml}, \mathrm{pH} 7.4$ ) containing $0.05-0.25$ $\mu \mathrm{Ci} / \mathrm{ml}$ was pipetted into a test tube and pre-incubated at 37 ${ }^{\circ} \mathrm{C}$ for $15 \mathrm{~min}$. An erythrocyte suspension (packed cells: Krebs Ringer bicarbonate buffer, 1:1 by vol, $1 \mathrm{ml}$ ) was then added, oxygenated and incubated. The media was shaken mechanically throughout the incubation period. At predetermined intervals $0.5 \mathrm{ml}$ of incubation medium was added to polypropylene conical tubes $(1.5 \mathrm{ml})$ containing $0.5 \mathrm{ml}$ of silicon oil ( $\rho$ 1.07) and centrifuged for $20 \mathrm{~s}$ in a Beckmann Microfuge B [32]. Aliquots of the supernatant fluid $(0.1 \mathrm{ml})$ were taken for scintillation counting, the remainder being removed by aspiration. Extra care was taken not to aspirate portions of the pellet while removing the oil. $\mathrm{H} 2 \mathrm{O}(0.25 \mathrm{ml})$ was then added to the packed cells with vigorous mixing. The resulting haemolyzed erythrocytes were bleached with $10 \%$ trichloroacetic acid $(0.25 \mathrm{ml})$. The denatured material was sedimented by centrifugation and a $0.1 \mathrm{ml}$ sample of supernatant fluid was taken for scintillation counting.

Under these incubation conditions, with extracellular chloride $\sim 40 \mathrm{mM}$, chloride ions efflux from the cell at the onset of the incubation due to the chloride concentration gradient across the erythrocyte membrane. This net flux creates a diffusion potential which is positive inside. This diffusion potential increases both the initial rate and the distribution ratio of glucose (unpublished observations). These incubation conditions were used throughout the study. Similar results were obtained by substituting Krebs Ringer bicarbonate buffer by phosphate/citrate, Tris- $\mathrm{HCl}$, Sorenson's phosphate or glycine/ $\mathrm{NaOH}$ buffers ( $\mathrm{pH}$ 7.4). During the initial phase of uptake experiments, the influx of glucose into human erythrocytes is effectively irreversible and is pseudo-zero order [7]. The rate of influx of glucose (1 to $20 \mathrm{mM}$ ) was linear for time period up to 5 min. Fixed time assays were run either for $1 \mathrm{~min}$ or $2 \mathrm{~min}$ intervals. Values are presented as mean $\pm \mathrm{SD}$, based on 3 measurements per sample.

It is assumed that the properties of the $\mathrm{D}-\left[{ }^{12} \mathrm{C}\right]$ glucose tracer do not differ from those of the nonradioactive D$\left[{ }^{12} \mathrm{C}\right]$ glucose.

\section{Results}

Miller [33] investigated several methods of measuring glucose flux across human red blood cell membranes, using the Ørskov [34] light scattering technique. 
Table 1. Glucose transport across the human red blood cell membrane

\begin{tabular}{|c|c|c|c|}
\hline Procedure & Direction & $V_{\max }(\mathrm{mM} / \mathrm{min})$ & $K_{\mathrm{m}}(\mathrm{mM})$ \\
\hline zero-trans & inside $\rightarrow$ outside outside $\rightarrow$ inside & $\begin{array}{lr}V_{1 \rightarrow 2}{ }^{\mathrm{zt}} & 129.0 \\
V_{2 \rightarrow 1}{ }^{\mathrm{zt}} & 32.0\end{array}$ & $\begin{array}{lr}K_{1 \rightarrow 2}{ }^{\mathrm{zt}} & 25.0 \\
K_{2 \rightarrow 1}{ }^{\mathrm{zt}} & 1.8\end{array}$ \\
\hline Infinite-cis & $\begin{array}{l}\text { inside } \rightarrow \text { outside } \\
\text { outside } \rightarrow \text { inside }\end{array}$ & $\begin{array}{lr}V_{1 \rightarrow 2} \text { ic } & 132.0 \\
V_{2 \rightarrow 1} \text { ic } & 85.0\end{array}$ & $\begin{array}{ll}K_{1 \rightarrow 2}{ }_{\text {ic }} & 1.9 \\
K_{2 \rightarrow 1} & 2.8\end{array}$ \\
\hline 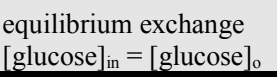 & $\begin{array}{l}\mathrm{D}-\left[{ }^{12} \mathrm{C}\right] \text { glucose } \\
\text { in or out } \\
\text { both directions }\end{array}$ & $\begin{array}{l}V_{1 \rightarrow 2}=\mathrm{V}_{2 \rightarrow 1} \\
=\mathrm{V}^{\mathrm{ee}} \quad 310.0\end{array}$ & $K_{\mathrm{m}}^{\mathrm{ee}}$ \\
\hline
\end{tabular}

NB: Fluxes are always considered to be measured from the cis to the trans solution. So, either solution could be the cis for influx or efflux ; the other solution would be then the trans for efflux or influx.

Adapted from: Naftalin, R.J. and Holman, G.D. (1977) Transport of Sugars in Human Red Blood Cells, in Membrane Transport in Red Cells, Ellory, J.C. and Lew, V.L. (eds), pp.257-300. London: Academic Press; Lieb, W.R. (1982) A Kinetic Approach to

Transport Studies, in Red Cell Membranes A Methodologycal Approach, Ellory, J.C. and Young, J.D. (eds), pp.135-164. London: Academic Press ; Naftalin, R.J. (2008)

"Alternating carrier model of asymmetric glucose transport violate the energy conservation laws", Biophysical J., vol.95, pp.4300-4314.

The transport of D-glucose mediated by GLUT1 [35] is inhibited by cytochalasin B, sugar transport inhibitor, at a stoichiometric ratio of $1: 1[36,37]$. Also, since haemoglobin is by the far the major protein constituent of

the RBC cytoplasm, the removal of the internal contents of $\mathrm{RBC}$ has a marked effect on glucose flux asymmetry system because haemoglobin affects the glucose transport kinetics [38].

The presence of very significant trans acceleration immediately supports the model of facilitated transport for consideration. Also, the various $K_{\mathrm{m}}$ values are not uniformed, and the human RBC glucose system is overwhelmingly complicated than even a simple carrier though heterosacharides fluxes [39] supports the notion of fixed number of carrier molecules within the membrane [40].

\section{The Carrier Hypothesis}

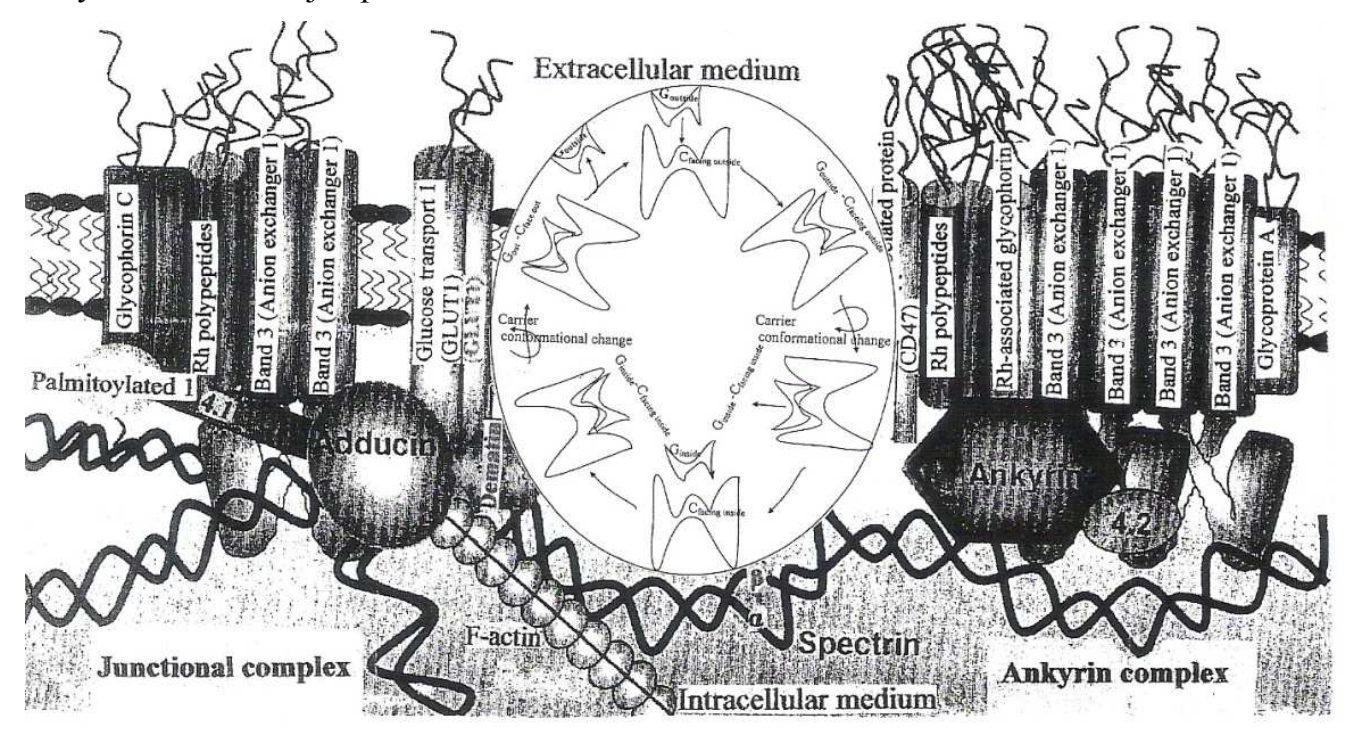

txt

Fig 3. The alternating conformation model of $\alpha-D$ - glucose ( 1 ) carrier in human erythrocyte by GLUT1. The glucose cooperative tetramer of proteins carrier is proposed to exist in one of two conformation, with a binding site for glucose facing either outside or inside of the cell. A complex of glucose-carrier results from the binding of glucose to its site that cause re-orientation of the protein carrier, so that the glucose gains access to the opposite side of the RBC membrane in a three-mode sequential cycle.

The properties of specificity, saturation and competition suggests that a specific chemical site within the membrane called GLUT1 is able to combine with the transported glucose [39, 41, 42]. GLUT1 associates with stomatin, a cholesterol-binding, structural/scaffolding protein that forms large oligomeric complexes associated with cholesterol-rich membrane domains; its absence in RBC disorder may condition the differential recruitment of channel and transporter glycoproteins to structured membrane microdomains $[43,44]$. The carrier hypothesis is a model that attempts to explain the properties of facilitated transport in terms of the movements of the carrier and the carrier-glucose complex (Fig.3). The interaction of lipid raft-associated membrane protein with GLUT1 regulates 
the distinctive transport properties of GLUT1 in human RBC.The simultaneous existence of both an outward-facing and inward- facing carrier binding sites cannot occur within a single glucose transporter [45, 46] of three mediated events [47].

The phenomenon of trans-acceleration of glucose flux through RBC membranes is very interesting; unlabeled Dglucose on one side of the membrane stimulates the transport of $\left[{ }^{12} \mathrm{C}\right]$ glucose from the other (trans) side [23, 48, 49]. This is ramified on the basis that rate constant of an empty carrier re-orientation is less than that of a loaded

MUSCLE

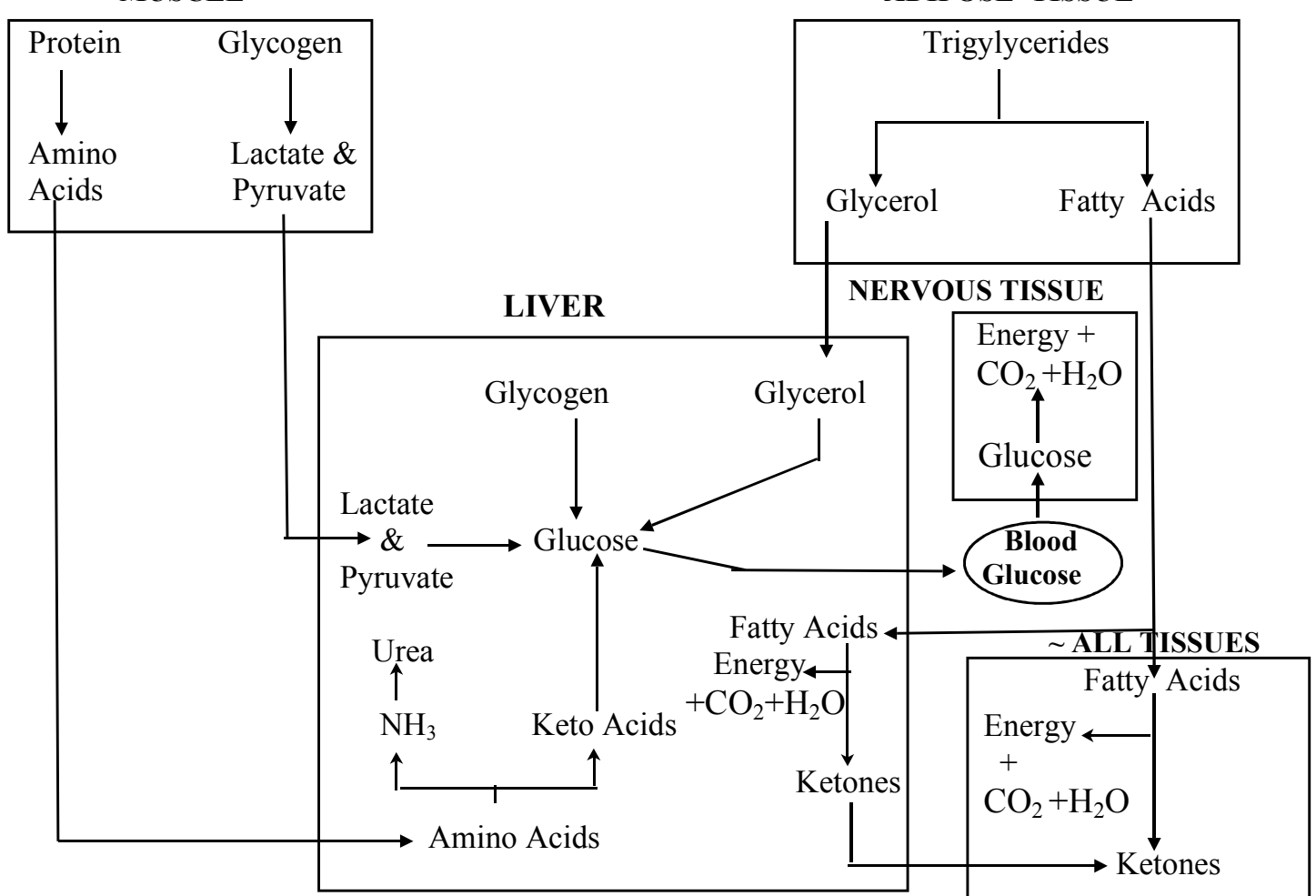

( EXCLUDING NERVOUS TISSUES)

carrier. Also, this phenomenon rules out inside / outside two sites load carrier re-orientation [40].

The mature human RBCs express functional insulin receptors, as demonstrated by increased calcium flux and tyrosine phosphorylation in response to insulin [50].

Adapted from: Hajjawi, O.S. (2013) "Ionic and osmotic equilibria of human red blood cells", American J. Sci. Res., vol.86, p.181; Hajjawi, O.S. (2013) "Human red blood cells-2”, American Journal of life Sciences, vol.1(5), p.221.

\section{Sources of Blood Glucose}

ADIPOSE TISSUE 
amino acids that permeate liver to be converted into keto acids and in turn to glucose [54].

Adapted from: Campbell, M.K. and Farrell, S.O. (2006) Biochemistry, $5^{\text {th }}$ edn. Belmont, CA: Thomson Learning, Inc.; Nelson, D.L. and Cox, M.M. (2008) Lehninger Principles of Biochemistry, $5^{\text {th }}$ edn. New York, NY: W.H.Freeman and Company.

A simple calculation reveals that the $180 \mathrm{~g}$ of glucose per day [4] produced by the liver during fasting would not be enough to meet all the body's energy needs:

$180 \mathrm{~g} /$ day x $4 \mathrm{kcal} / \mathrm{g}=720 \mathrm{kcal} /$ day $(3013 \mathrm{~kJ} /$ day $)$. The normal total energy expenditure is $\sim 1800 \mathrm{kcal} /$ day $(7531$ $\mathrm{kJ} /$ day) and the brain itself consumes about $18 \%$ of the basal metabolic rate that equates to $324 \mathrm{kcal}(1356 \mathrm{~kJ})$, or $80 \mathrm{~g}$ of glucose ([55]. The brain consumes $\sim 25 \%$ of total body glucose consumption.

An approximately 1.334 calories $(5.581$ Joule $)$ is required every hour for every $1000 \mathrm{~g}$ of body weight [56]. Hence, a man weighing $60 \mathrm{Kg}$ would require $1.334 \times 24 \mathrm{hrs}$ $\times 60 \mathrm{Kg}=1921 \mathrm{cal} /$ day.

The Dietary Guidelines for Americans [57] recommends the following blend:

- $\quad 45-65 \%$ Carbohydrates (sugar, sweets, bread, cakes)

- $\quad 20-35 \%$ Fat (dairy products, oil)

- $\quad 10-35 \%$ Protein (eggs, milk, meat, poultry, fish)

Sadava and Orians [55] and Begum [58] reported Let us consider for the purpose of this example and calculate the values for a man of $60 \mathrm{~kg}$ in body weight as follows:

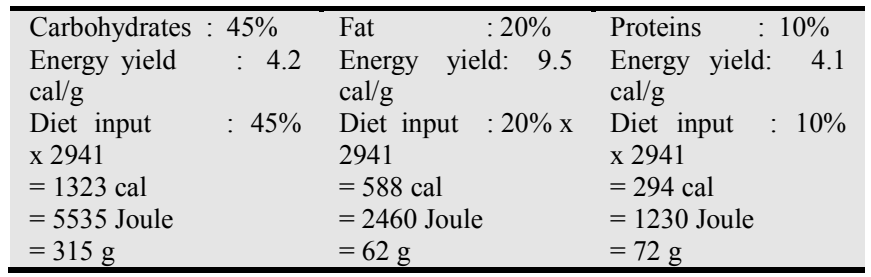

Glucose is the principal source of energy for mammalian cells and its transport is mediated by a group of membrane transport proteins and it is a universally conserved property (Fig. 4). Human RBC expresses the highest level of GLUT1 with more than $2 \times 10^{5}$ molecules per cell where GLUT1 accounts for $10 \%$ of total protein mass [59]. The GLUT4 is an insulin-regulator glucose membrane transporter found in adipose tissues whereas GLUT4 is insulin dependent [60].

Several other hormones (e.g. glucagon, growth hormone, catecholamines, and corticosteroids) oppose insulin action and they increase blood glucose [61].

\section{Insulin}

The blood concentration is influenced by hormones which facilitate its entry or removal from the circulation (Fig. 4). Insulin that its functions are anabolic, is produced by beta $(\beta)$ cells and peptide hormone glucagon is made and secreted in alpha $(\alpha)$ cells of the endocrine pancreas within specialized areas called the islets of Langerhans
$[4,62]$. The most important hormone involved in glucose metabolism is insulin for the following reasons : (1) it decreases blood glucose by enhancing glucose uptake through GLUT4 and its in metabolism by liver, muscle, adipose tissue and other tissues, as well as its ability to inhibit gluconeogenesis and glyconolysis, (2) it increases fatty acids and triglycerides synthesis, thus increasing fat storage (adipogenesis) and promoting glycogen synthesis in the liver, (3) it stimulates the transport of free amino acids into the liver and muscle cells for protein synthesis; it inhibits the catabolism of proteins, and (4) it induces the cellular uptake of $\mathrm{K}^{+}, \mathrm{HPO}_{4}{ }^{2-}$ and $\mathrm{Mg}^{2+}$.

Insulin release into the blood stream is usually triggered as a consequence of blood glucose level increase after a carbohydrate-rich meal [63]; insulin does not facilitate glucose uptake in human RBC [64,65]. Unfortunately, insulin deficit will have the opposite results, especially as high rates of glucose uptake and net anabolism of glycogen, protein and triglycerides (Fig. 4) which depend on the presence of high concentration of insulin in the blood stream [66]. The glucose can be utilized by the brain because its glucose uptake is not insulin dependent [67].

\section{Diabetes Mellitus}

It is a variable disorder (disease) of carbohydrate metabolism caused by a combination of hereditary and environmental factors and usually characterized by inadequate secretion or utilization of endogenous insulin; so that excess blood glucose ( $>126 \mathrm{mg} / \mathrm{dl}$ or $7.0 \mathrm{mmol}$ ) cannot be mediated nor absorbed into the target cells that require it in the body, hyperglycemia [68].The classical symptoms of diabetes are: polyuria, polydipsia, polyphagia and weight loss $[58,69]$. F. Banting and J.J.R. MacLeod shared the 1923 Nobel Prize for Physiology and Medicine for their work on "discovering" insulin. Since insulin's discovery, medical breakthroughs continued to prolong and ease the lives of people with diabetes. Roger Hinsworth in 1935 discovered there were two types of diabetes: "insulin sensitive" (TI DM) resulted from autoimmune destruction of insulin producing beta cells of the pancreas due to low level of protein interleukin-2, and "insulin insensitive" (TII $\mathrm{DM}$ ) that is related to high fat levels in the pancreas and the liver and it is characterized by peripheral insulin resistance and impaired insulin secretion from pancreatic $\beta$ cells $[23$, 68]. By differentiating between the two types of diabetes, Hinsworth helped open up new avenues of diabetes treatment [69], as the primary concern is that there is cell degeneration.

The reasons for inadequate insulin may include lack of hormone production by $\beta$-cells of the pancreas, reduction in insulin receptor signaling, or insufficient active GLUT4 [68, $70,71]$. Simvastatin is a medicine that is used to reduce the amount of cholesterol produced in the body in order to minimize the chances of a heart attack or stroke in people who have heart disease, dyslipidaemia and to minimize the chances of a heart attack or stroke in people who have 
diabetes [9].

Various cytokines, including tumor necrosis factor (TNF), growth hormone $(\mathrm{GH})$ and interleukin (IL)-6, induce insulin resistance. It was demonstrated that induction of suppressor of cytokine signaling (SOCS)-3 by TNF and GH is an important mechanism by which these cytokines, obesity and pregnancy impair insulin sensitivity $[72,73$, 74]. In pregnancy, progesterone can cause insulin resistance and results in gestational diabetes [75]; pregnancyassociated hormones at $55-200 \mathrm{ng} / \mathrm{ml}$ during third trimester may contribute to insulin resistance and secondary hyperlipidemic [76]. Prediabetes is when people have blood glucose levels higher than normal but not high enough for a diagnosis of diabetes; this condition raises the risk of developing TII DM diabetes, heart disease, and stroke $[68,69]$.

Diabetes treatment varies depending on the type and severity of disease, but there is no cure short of a pancreas transplant that can lead to a variety of serious complications and risks. Could be a future without diabetes? The hyperglycaemia part of diabetes is conceptually simple, i.e. restoring insulin producing cells through Islet cell transplantation, artificial pancreas, immunotherapy, vaccination, stem cells treatment and others trends in future research in pursue of a cure.

\section{References}

[1] H. Dryerre, W.G. Millar, and E. Ponder (1926) "An investigation into the size of human erythrocytes before and after exercise", Experimantal Physiology, vol. 16, pp.69-86.

[2] P.B. Canham and A.C. Burton (1968) " Distribution of size and shape in population of normal human red cells", Circ. Res., vol. 22, pp. 405-422.

[3] R.I. Sha'afi (1977) Water and Small Nonelectrolyte Permeation in Red Cells, in Ellory, J.C. and Lew, V.L.(eds.) ,Membrane Transport in Red Cells, pp.221- 256. London: Academy Press Inc. (London) Ltd.

[4] W.F. Ganong (2003) Medical Physiology, 21 $1^{\text {st }}$ edn. Los Altos,CA: Lange Medical.

[5] G. W. Gould (1997) Facilitative Glucose Transporters. Austin, TX: R.G. Landas Co.

[6] J.C.Ellory and V.L. Lew (1977) Membrane Transport in Red cells. London: Academic Press.

[7] L.Michaelis and M.L.Menten (1913) "Die kinetik der invertinwirkung ”, Biochem. Zeitschr, vol.49, pp.333-369.

[8] L.Michaelis, M.L.Menten, K.L. Johnson, and R.S. Goody, (2011) "The original Michaelis constant: translation of the 1913 Michaelis-Menten paper", Biochemistry, vol.50 (39), pp.8264-8269.

[9] D.L. Nelson and M.M.Cox (2008) Lehninger Principles of Biochemistry, $5^{\text {th }}$ edn. New York, NY: W.H.Freeman and Company.

[10] E. Beutler (1996) "G6PD population on genetics and clinical manifestations”, Blood Rev, vol.10, pp.45-52.
[11] L. Luzzatto (2006) "Glucose 6-phosphate dehydrogenase deficiency: from genotype to phenotype ", Haematologica, vol.91, pp.1303-1306.

[12] L. Bordin, F. Zen, F. Ion-Popa, M. Barbetta, B. Baggio and G. Clari (2005) "Band 3 tyr-phosphorylation in normal and glucose-6-phospate dehydrogenase- deficient human erythrocytes", Mol. Membr. Biol., vol.22 (5), pp.411-420.

[13] J.E. Frank (2005) "Diagnosis and management of G6PD deficiency”, Am. Fam. Physician, vol. 72, pp.1277-1282.

[14] A.L. Peters and C.I.F.Van Noorden (2009) "Glucose-6phosphate dehydrogenase deficiency and malaria: cytochemical detection of heterozygous G6PD deficiency in women", J. Histochem Cytochem, vol. 57 (11), pp.10031011 .

[15] G. Jacobasch and S.M. Rapoport (1996) "Hemolytic anemias due to erythrocyte enzyme deficiencies", Mol. Aspects. Med., vol.17 (2), pp.143-170.

[16] S. H. Webster (1949) "Heinz body phenomenon in erythrocytes a review", Blood, vol.4 (5), pp.479-497.

[17] W.T. Potter, S. Rong, J. Griffith, J. White and V.F. Garry(1991) "Phosphine- mediated Heinz body formation and hemoglobin oxidation in human erythrocytes", Toxicol Lett. , vol.57(1), pp.37-45.

[18] S.J. Singer and G.L. Nicholson (1972) "The fluid mosaic model of the structure of cell membrane", Science, vol.175, pp.720-731.

[19] E. Kajii (1998) "Advance in the Rh blood group system", Nihon Hoigakn Zasshi, vol.52 (1), pp.1-18.

[20] P.G. Gallagher and S.E. Lux (2003) Disorders of the Erythrocyte Membrane, in Hematology of Infancy and Childhood, Nathan,D.G., Orkin, S.H., Ginsberg, D. and Look, T.A. (eds), p.560-684. Philadelphia, PA : WB Saunders.

[21] J.F. Flatt and L.J.Bruce (2009) "The hereditary stomatocytoses", Haematologica, vol. 94 (8), pp.1039-1041.

[22] M.E. Reid and C. Lomas-Francis (2004) The Blood Group Antigen Facts Book, $2^{\text {nd }}$ edn. New York, NY: Elsevier Academic Press.

[23] I. Bernhardt and J.C. Ellory (2003) Red Cell Membrane Transport in Health and Disease. Berlin: Springer-Verlag.

[24] P.H.B. Bolton-Maggs, R.F. Stevens, N.J. Dodd,G. Lamont, P. Tittensor and M.J.King (2004) "Guidelines for the diagnosis and management of hereditary spherocytosis", British Journal of Haematology,vol.126, pp.455-474. doi:10.1111/j.1365-2141.2004.05052.x

[25] R.M. Bannerman and J.H. Renwick (1962) " The hereditary elliptooytoses: clinical and linkage data", Annals Human Genetics Lond., vol.26 (1), pp.23-38.

[26] J. Knight and D.R. Czuchlewski (2013) "Acquired elliptocytosis of myelodysplastic Syndrome", Blood, vol. $121(4)$, p. 572.

[27] C.J. Parker (2002) "Historical aspects of paroxysmal nocturnal haemoglobinuria: 'defining the disease' “, Br.J. Haematol. , vol.117, pp. 3-22.

[28] D.J. Araten, H.T. Thaler and L. Luzzatto (2005) "High 
incidence of thrombosis in African-American and LatinAmerican patients with paroxysmal nocturnal Haemoglobinuria", Thromb Haemost, vol.93, pp. 88-91.

[29] W.W. Umbreit, R.H. Burris and J.F. Stauffer (1946) Manometric Techniques, p.194. Minneapolis, MN: Burgess Publishing Co.

[30] C.G. Winter and H.N. Christensen (1964) "Contrasts in neutral amino acid transport and rabbit erythrocyte and reticulocytes", J. Biol. Chem, vol.239, pp.872-878.

[31] E. Eavenson and H.N. Christensen (1967) "Transport systems for neutral amino acids in the pigeon erythrocyte", J.Biol. Chem., vol.242, pp. 5386-5396.

[32] R. Rosenberg and O.J. Rafaelsen (1979) "Transport of neutral amino acids across the human red blood cell membrane", J.G.Physiol, vol 41, pp.289-296.

[33] D.M. Miller (1968) "The kinetics of selective biological transport. III. Erythrocyte- monosaccharide transport data", Biophys $J$, vol.8, pp. 1329-1338.

[34] S.L. Ørskov (1935) "A method for continuous photographic recording of volume changes in red blood cells. Studies on the influence of temperature and of hydrogen- ion concentration on the rate of permeability of glycerol and urea" Biochem, Z., vol.279, pp.241-249.

[35] J.F. Leitch and A. Carruthers (2009) " $\alpha$-and $\beta$ Monosacharide transport in human erythrocytes", Am. $J$ Physiol. Cell physiol., vol.296 (1), pp.C151- C161.

[36] M.A. Zoccoli,S.A. Baldwin and G.E. Lienhard (1978) "The monosaccharide transport system of the human erythrocyte. Solubilization and characterization on the basis of cytochalasin B binding", J.Biol. Chem., vol.253, pp.69236930.

[37] E.K. Cloherty, K.S. Heard and A. Carruthers (2001) "The red blood cell glucose transporter presents multiple ,nucleotide-sensitive sugar exit sites", Biochemistry, vol.40 (51), pp. 15549-15561.

[38] L.E. Lenox, J.M. Perry and R.F. Paulson (2005) "BMP4 and $\mathrm{MaCDS}$ and MADH regulate the erythroid response to acute anemia", Blood, vol.105, pp.2741-2748.

[39] G.F. Baker and R.J. Naftalin (1979) "Evidence of multiple operational affinities for D- glucose inside the human erythrocyte membrane", Biochim. Biophys. Acta, vol.550, pp.474-484.

[40] A. Carruthers, J. De Zutter, A. Ganguly and S. Devaskar (2009) "Will the original glucose transporter isoform please stand up", Am. J. Physiol. Endocrinol. Metab, vol.297 (4), pp. E836-E848.

[41] W.D. Stein (1989) "Kinetics of transport: analyzing, testing, and characterizing models using kinetic approaches", Methods Enzymol.,vol.171, pp.23-62.

[42] E.M. Wright, D.D.F. Loo and B.A. Hirayama (2011) "Biology of human sodium glucose transporters", Physiol Rev, vol. 91(2), pp.733-794

[43] J.Z. Zhang, W. Abbud, R. Prohaska and F. Ismail-Beigi (2001) "Overexpression of stomatin depression GLUT-1 glucose transporter activity", Am.J.Physiol. Cell Physiol., vol.280, pp.C1277-1283.
[44] U. Salzer, M. Mairhofer and R. Prohaska (2007) " Stomatin: a new paradigm of membrane organization emerges", $D Y N$ Cell Biol., vol.1, pp.20-33.

[45] A.G. Lowe and A.R. Walmsley (1986) "The kinetics of glucose transport in human red blood cells", Biochim Biophys Acta, vol. 857, pp. 146-154.

[46] R.J. Naftalin (2008) “Alternating carrier model of asymmetric glucose transporter violate the energy conservation laws", Biophysical J., vol.95, pp.4300-4314.

[47] D.M. Blodgett and A. Carruthers (2005) "Quench-flow analysis reveals multiple phases of GluT1-mediated sugar transporter", Biochemistry, vol.44 (7), pp.2650-2660.

[48] P.K. Gasbjerg and J. Brahm (1991) "Glucose transport kinetics in human red blood cells",Biochim. Biophys. Acta, vol.1062(1), pp. 83-93.

[49] Vollers, S. S. (2013) "Identification and analysis of the domain required for trans- acceleration kinetics in the human glucose transporter GLUT1: a dissertation", University of Massachusetts Medical School. Retrieved May 29, 2013 from http://escholarship.umassmed.edu/gsbs_diss/645

[50] P. Zancan and M. Sola-Penna (2005) "Calcium influx: a possible role for insulin modulation of intracellular distribution and activity of 6-phosphofructo- 1-kinase in human erythrocytes", Mol. Cenet. Metab., vol.86, pp.392400 .

[51] A. Casey, R. Mann, K. Banister, J. Fox, P.G. Morris, A. Ian, I.A. Macdonald and P.L. Greenhaff (2000) "Effect of carbohydrate ingestion on glycogen resynthesis in human liver and skeletal muscle, measured by ${ }^{13} \mathrm{C}$ MRS", Am.J. Physiology-Endo, vol. 278 no. 1, pp.E65-E75

[52] L. Stryer (1995) Biochemistry, $4^{\text {th }}$ edn. New York, NY: H.W. Freeman and Company.

[53] M. Elia (2000) "Hunger disease", Clin. Nutr., vol.19 (6), pp.379-386.

[54] G.F. Cahill and R.L. Veech (2003) "Ketoacids? Good medicine?", Trans. Am. Clin. Clim. Ass., vol. 114, pp.149163.

[55] D. Sadava and G. Orians (2000) Life: The Science of Biology. New York, NY: W. H. Freeman and Co.

[56] British Athletic Federation (1992) Senior Coach - Coaching Theory Manual. 3rd edn. Windsor, Berkshire: Reedprint Ltd.

[57] Dietary Guidelines for Americans (2010) “Evolution of the Dietary Guidelines for Americans 2005 to 2010”. Retrieved June 23, 2013 from http://www.nationaldairycouncil.org/SiteCollectionDocume nts/education_materials/dietary_guidance.

[58] R.M. Begum (2008) Textbook of Foods, Nutrition \& Dietetics, $3^{\text {rd }}$ edn. Okhla Industrial Area, New Delhi,India: Sterling Publishers Pvt. Ltd.

[59] A.L. Helgerson and A. Carruthers (1987) "Equilibrium ligand binding to the human ertythrocyte sugar tranporter: evidence for two sugar-binding sites per carrier", J.Biol. Chem., vol.262, pp. 5464-5475.

[60] A.L. Olson (2012) "Regulation of GLUT4 and insulindependent glucose flux", Mol. Biol., vol.2012, Article ID 
856987. Retrieved June 23, 2013 from http://www.hindawi.com/isrn/mb/2012/856987. doi: $10.5402 / 2012 / 856987$

[61] P.J. O’Connor, N. Bodkin,J. Fradkin, R. Glasgow,S. Greenfield, E. Gregg, E.A. Kerr, L.G. Pawlson, J.V. Selby, J.E. Sutherland, M.C. Taylor and C.H. Wysham (2011) " Diabetes performance measures: current status and future directions", Diabetes Care, vol. 34, pp.1651-1659 ; pp.1651-1659.

[62] J. Seifter, A.Ratner and D. Sloane (2005) Concepts in Medical Physiology. Baltimore, MD: Lippincott Williams \& Wilkins.

[63] H. Yang, D. Wang, K. Engelstad, L. Bagay, Y. Wei, M. Rotstein, V. Aggarwal, B. Levy, L. Ma, W.K. Chung and D.C. De Vivo (2011) "Glut1 deficiency syndrome and erythrocyte glucose uptake assay", Ann. Neurol., vol.70, pp.996-1005.

[64] P.R. Shepherd and B.B.Kahn (1999) "Glucose transporters and insulin action implications for insulin resistance and diabetes mellitus", N. Engl. J. Med., vol. 341 (4), pp. 248257 .

[65] T.E. Graham and B.B. Khan (2007) "Tissue-specific alterations of glucose transport and molecular mechanisms of intertissue communication in obesity and type 2 diabetes", Horm. Metab. Res.,vol. 39(10), pp.717-721.

[66] G. Wilcox (2005) "Insulin and insulin resistance", Clin. Biochem. Rev., vol. 26 (2), pp.19-39.

[67] E.M. Bingham, D. Hopkins, D. Smith, W. Pernet, W Hallett, L. Reed, P.K. Marsden and S.A. Amiel (2002) "The role of insulin in human brain glucose metabolism: an ${ }^{18}$ Fluorodeoxyglucose positron emission tomography study", Diabetes, vol. 51 (12), pp. 3384-3390.

[68] D. Brealey and M. Singer (2009) " Hyperglycemia in critical illness: a review”, J. Diabetes Sci. Technol., vol. 3(6), pp.
1250-1260.

[69] R.A. De Fronzo, E. Ferrannini, H. Keen and P. Zimmet (2004) International Textbook of Diabetes Mellitus, vol. 1. $3^{\text {rd }}$ edn. Hoboken, NJ: John Wiley \& Sons.

[70] R.M. O’Brien and D.K. Granner (1996) "Regulation of gene expression by insulin", Physiol Rev., vol. 76, pp.11091161.

[71] P. Cohen (2006) "The twentieth century struggle to decipher insulin signaling”, Nat. Rev. Mol. Cell Biol., vol. 7, pp. 867873.

[72] M. Bluher, J. Kratzsch and R. Paschke (2001) " Plasma levels of tumor necrosis factor-alpha, angiotensin II, growth hormone, and IGF-I are not elevated in insulin-resistant obese individuals with impaired glucose tolerance", Diabetes Care, vol.24, pp. 328-334.

[73] B.M. Spiegelman and J.S.Flier (2001) " Obesity and the regulation of energy balance”, Cell, vol. 104, pp.531-543.

[74] M. Fasshauer, S. Kralisch, M. Klier, K. Lossner, M.M. Bluher, J. Klein and R. Raschke (2004) "Insulin resistanceinducing cytokines differentially regulate SOCS mRNA expression via growth factor- and Jak/Stat-signaling pathways in 3T3-L1 adipocytes", J. Endocrinology, vol.181, pp. 129-138.

[75] T. Wada, S. Hori, M. Sugiyamu, E. Fujisawa, T. Nakano, H. Tsuneki, K. Nagira, S. Saito and T. Sasaoka (2010 "Progesterone inhibits glucose uptake by affecting diverse steps of insulin signaling in 3T3-L1 adipocytes", Am. J. Physiol-Endo, vol.298 (4), pp. E881-888.

[76] Bannerman, R. M. and Renwick, J. H. (1962) "The hereditary elliptooytoses: clinical and linkage data", Annals Human Genetics Lond., vol.26 (1), pp.23-38. 